\title{
METODE MODIFIED WEIGHTED MINKOWSKI UNTUK PENGEMBANGAN SISTEM PENALARAN BERBASIS KASUS
}

\author{
Edi Faizal \\ Program Studi Manajemen Informatika STMIK AKAKOM Yogyakarta \\ Jl. Raya Janti Karang Jambe No. 143 Yogyakarta 55198 \\ Email: edifaizal@akakom.ac.id
}

\begin{abstract}
Knowledge acquisition process is not easy, because of the different levels of expertise even though all true. Computer experts had tried other methods to resolve the problem of the acquisition, which is known as case-based reasoning. Representation of knowledge in CBR is a collection of previous case.

This research focus is the application of CBR for diagnosing womb diseases. The level of similarity is calculated by using the modified weighted Minkowski. Methods of data collection are interviews, observation and study of literature.

The test results show the system can be recognize the womb disease correctly is $94.44 \%$ (sensitivity), specitifity rate of $57.14 \%$, PPV of $85.00 \%$ and $80.00 \%$ NPV. The system have an accuracy rate of $84.00 \%$ with an error rate of $16.00 \%$.
\end{abstract}

Keyword: cbr, modified weighted minkowski, womb disease.

\section{PENDAHULUAN}

Penerapan teknologi komputer untuk mengerjakan pekerjaan manusia diwujudkan dengan meniru sistem kecerdasan manusia dalam berfikir Bagian ilmu komputer yang mempelajari hal tersebut dikenal dengan istilah kecerdasan buatan/artificial intelligence (Kusumadewi, 2003).

Salah satu implementasi kecerdasan buatan adalah sistem pakar (expert system). Sistem ini bekerja dengan meniru atau menduplikasi kepakaran seseorang (human expert), sehingga komputer dapat melakukan pekerjaan layaknya seorang pakar dalam bidang tertentu (Kusrini, 2006).

Mengingat sulitnya proses akuisisi dalam pengembngan siste pakar, para ahli komputer mencoba memepelajari metode lain penyelesaian masalah dengan memperlajari penyelesaian masalah berdasarkan pengalaman yang dikenal dengan penalaran berbasis kasus (case-based reasoning).

Representasi pengetahuan dari sebuah case-based reasoning/CBR berupa kumpulan kasus (case base) yang pernah terjadi sebelumnya. Selanjutnya dalam menyelesaikan suatu 
permasalahan, CBR menggunakan solusi dari kasus terdahulu yang mirip dengan kasus saat ini. Proses mencari kedekatan (similarity) antara kasus baru dengan kasus lama dapat menggunakan berbagai macam metode. Salah satu metode yang dapat digunakan weighted minkowski. Penelitian Faizal (2013) telah berhasil memodifikasi kekurangan yang dimiliki weighted minkowski dalam menyimpulkan hasil diagnosa penyakit cardiovascular.

CBR dapat diimplementasikan dalam berbagai bidang seperti bisnis, hukum, desain, rekayasa, sejarah dan dalam bidang kedokteran serta berbagai bidang yang lainya. Khusus pada bidang kedokteran, seorang dokter pada umumnya melakukan diagnosa penyakit pasien dengan menanyakan gejala yang dirasakan atau terlihat pada pasien, kemudian melakukan penalaran berdasarkan pengetahuan yang dimilikinya. Selain itu, dokter akan melihat kasus terdahulu yang pernah ditangani dengan tingkat kemiripan yang paling tinggi untuk selanjutnya menentukan hasil diagnosa dan solusi pengobatan (Faizal, 2013).

Tidak dapat dipungkiri bahwa sebagian besar masyarakat di Indonesia didominasi oleh kaum wanita. Sangat penting diperhatikan kesehatan bagi kaum wanita ini, terutama dalam hal ini adalah kesehatan kandungan bagi ibu hamil. Penyakit atau gangguan pada kandungan jika tidak mendapat penanganan yang baik akan mengakibatkan kematian terutama pada ibu hamil. Hal ini nantinya juga berpengaruh terhadap angka kematian bayi yang sedang dikandungnya (Faizal, 2014).

Wanita mempunyai sistem reproduksi, dimana terdapat alat kelamin luar dan alat kelamin dalam. Alat kelamin luar mempunyai fungsi sebagai jalan masuk sperma ke dalam tubuh wanita dan sebagai pelindung alat kelamin dari infeksi. Saluran kelamin wanita merupakan lubang yang berhubungan dengan dunia luar sehingga mikroorganisme penyebab penyakit masuk dengan mudah dan menginfeksi kandungan. Pada umumnya, mikroorganisme masuk melalui hubungan seksual (Yatim, 2005).

Keluhan pada penyakit kandungan memerlukan penanganan dan perawatan yang teliti dan frekuentif. Penyakit yang menyerang pada kandungan wanita tidak bisa dianggap sepele dan memerlukan campur tangan seorang 
pakar, sedangkan pakar untuk penyakit ini masih jarang dan dapat dipastikan membutuhkan biaya yang tidak kecil.

Pada penelitian ini akan dikembangkan sebuah sistem pakar yang dapat digunakan sebagai sarana untuk melakukan diagnosa awal terhadap gangguan kandungan. Penerapan sistem yang dikembangkan merupakan penerapan penalaran berbasis kasus. Perhitungan tingkat kemiripan (similarity) menggunakan metode modified weighted minkowski. Peran sistem pakar disini adalah untuk membantu (asisten) pakar dan kaum perempuan dalam melakukan diagnosa awal penyakit yang diderita.

\section{METODE PENELITIAN}

Langkah untuk melakukan diagnosa penyakit kandungan melalui sistem diwujudkan dengan adanya dialog antara penguna (user) dengan sistem berupa pertanyaan-pertanyaan. Masukan (input) system berupa data gejala (symtoms) yang dialami pasien, kemudian data tersebut dibuat menjadi kasus (new case). Proses pencocokan dilakukan dengan membandingkan tingkat kesamaan antara kasus baru dengan basis kasus (case base). Sedangkan keluaran (output) sistem adalah hasil diagnosa berupa prediksi penyakit kandungan yang dialami pasien, serta nilai similaritas/tingkat kemiripan (similarity) berdasar masukan gejala dari pengguna terhadap basis kasus. Nilai kemiripan antara 0 samapai dengan 1 (dalam bentuk persentase antara 0\% sampai dengan 100\%). Jika nilai kemiripan sama dengan 1, maka kasus lama tersebut sama persis dengan kasus baru, dan sebaliknya semakin kecil nilai similaritasnya maka semakin tidak mirip kasus tersebut.

Secara umum, gambaran proses dalam sebuah sistem case based reasoning/CBR dapat direpresentasikan sebagai suatu siklus proses (seperti terlihat pada Gambar 1) yang dibagi menjadi empat sub proses (Aamodt dan Plaza, 1994).

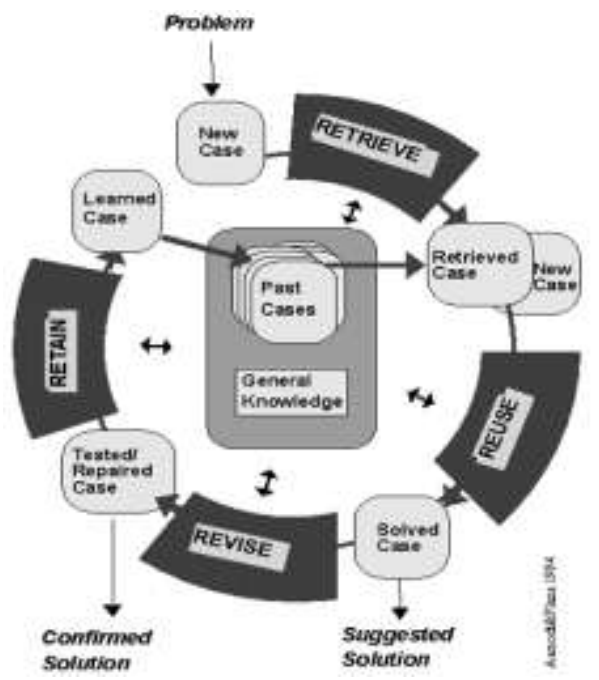

Gambar 1. Siklus CBR (Aamodt dan Plaza, 1994) 
1. Retrieve yaitu mencari kasus-kasus sebelumnya yang paling mirip dengan kasus baru.

2. Reuse yaitu menggunakan kembali kasus-kasus yang paling mirip tersebut untuk mendapatkan solusi untuk kasus yang baru.

3. Revise yaitu melakukan penyesuaian dari solusi kasus-kasus sebelumnya agar dapat dijadikan solusi untuk kasus yang baru.

4. Retain yaitu memakai solusi baru sebagai bagian dari kasus baru, kemudian kasus baru di-update ke dalam basis kasus

Metode yang diterapkan dalam penelitian untuk mengembangkan sebuah sistem penalaran berbasis kasus untuk mendiagnosa penyakit kandungan terdiri dari beberapa tahapan.

\section{Case Representation}

Kasus dapat direpresentasikan dalam berbagai bentuk, seperti representasi preposisional, representasi frame, representasi formlike dan kombinasi dari ketiganya (Pal dan Shiu, 2004). Penelitian ini memanfaatkan bentuk frame untuk merepresentasikan sebuah kasus, selanjutnya data kasus akan disimpan ke dalam database secara terindeks untuk mempercepat proses retrieval.

\section{Case Retrieval}

Retrieval merupakan inti dari CBR, yaitu proses menemukan dalam casebase, kasus-kasus yang paling dekat dengan kasus saat ini. Pengambilan kasus yang efektif harus menggunakan kriteria seleksi yang menentukan bagaimana basis kasus dicari. Teknik retrieval yang paling sering diselidiki sejauh ini, adalah $k$ nearest neighbor, pohon keputusan dan turunannya. Teknik ini menggunakan smimilarity metric untuk menentukan ukuran kedekatan (similarity) antar kasus (Pal dan Shiu, 2004). Pada penelitian ini metode similarity yang digunakan adalah weighted minkowski dengan persamaan (1) (Faizal, 2013).

$$
\begin{aligned}
& E(T, S)=\left(\frac{\sum_{k=1}^{n} \omega_{k}{ }^{r} * \mid d_{k}\left(S_{k} T_{k}\right) r}{\sum_{k=1}^{n} \omega_{k}^{r}}\right)^{1 / r} \times P(S) * \frac{f\left(S_{k}, T_{k}\right)}{j\left(T_{k}\right)} \\
& E\left(C_{i}, C_{j}\right) \quad: \quad \text { Nilai similaritas global antara } \\
& \omega_{k} \quad \text { : } \quad \begin{array}{l}
\text { kasus } C_{i} \text { dan kasus } C_{j} \\
\quad \text { Nilai bobot yang diberikan pada }
\end{array} \\
& d_{k}\left(c_{i k}, c_{j k}\right): \quad \begin{array}{l}
\text { atribut ke- } k \\
\text { Nilai similaritas lokal antara }
\end{array} \\
& \text { atribut } \mathrm{C}_{i} \text { ke- } k \text { dengan atribut } \mathrm{C}_{j} \\
& \text { ke- } k \\
& r \quad: \quad \text { Faktor minkowski (integer } \\
& T^{\prime}\left(C_{j}\right) \quad: \begin{array}{l}
\text { Positif) } \\
\text { tersentase tingkat kepercayaan suatu kasus dalam basis }
\end{array} \\
& \text { kasus } \\
& n\left(C_{i}, C_{j}\right): \quad \begin{array}{l}
\text { Jumlah atribut pada kasus baru } \\
\left(\mathrm{C}_{i}\right) \text { dan muncul pada kasus lama }
\end{array} \\
& \left(\mathrm{C}_{j}\right) \\
& n\left(C_{j}\right) \quad: \quad \text { Jumlah atribut yang terdapat } \\
& \text { pada kasus baru }\left(\mathrm{C}_{i}\right)
\end{aligned}
$$

Nilai $\mathrm{r}$ adalah bilangan prositif $\geq 1$, (antara 1 sampai dengan tak hingga). Pada penelitian yang dilakukan ini 
digunakan $r=3$. Penelitian sebelumnya yang dilakukan (Seetha et al, 2012) menunjukan bahwa dengan penggunaan $\mathrm{r}=3$ diperoleh hasil akurasi maksimum.

Similaritas lokal dibedakan menjadi dua jenis, yaitu symbolic dan numeric. Fitur symbolic dihitung dengan menggunakan persamaan (2) (Pal dan Shiu, 2004), Sedangkan fitur numeric akan dihitung dengan menggunakan persamaan (3) (Belkhairat et al, 2011).

$$
\begin{aligned}
& d_{k}\left(C_{i k}, C_{j k}\right)=\left\{\begin{array}{l}
1, \text { if } C_{i k}-C_{j k} \\
0, \text { if } C_{i k} \neq C_{j k}
\end{array}\right.
\end{aligned}
$$

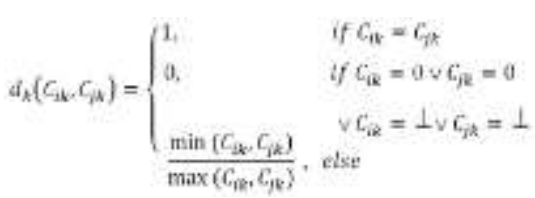

\footnotetext{
Keterangan:

$d_{k}\left(S_{k} T_{k}\right)$ : Kesumasn fitur ke-k dari saume case dar toryz cave

$\min \left(S_{b} T_{k}\right)$ : Nilai minimum atara fitur ke-k dari source case dan Larget case

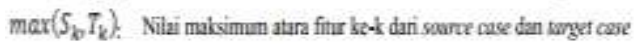

1 : Nilai tak kinggutidik ter definia (sclaie 0 dan I)
}

Jika tingkat kemiripan antara kasus lama dengan kasus baru memenuhi nilai threshold akan di-reuse, akan tetapi jika tidak maka pakar perlu memberikan kesimpulan solusi terhadap kasus baru tersebut.

\section{Case Revise}

Case revise (revisi kasus) merupakan bagian dari adaptasi sistem yang dilakukan oleh seorang pakar. Pakar akan merevisi nama penyakit beserta tingkat kepercayaan terhadap penyakit hasil diagnosa yang memiliki nilai similarity lebih kecil dari threshold $(0,8)$. Setelah kasus direvisi, selanjutnya kasus tersebut akan dijadikan sebagai basis kasus baru(proses retain).

Metode pengujian sistem untuk mengukur kemampuan sistem dalam melakukan diagnose dalam beberapa variasi. (Akobeng, 2007) menjelaskan bahwa sensitivitas dan spesifisitas digunakan untuk mengetahui tingkat akurasi. Analisis dilakukan dengan menggunakan 4 parameter yaitu TP, FP, TN dan FN. Selanjutnya digunakan menghitung sensitivitas (sensitivity), spesifisitas (specificity), nilai prediksi positif $(P P V)$ dan nilai prediksi negatif $(N P V)$. Perhitungan nilai-nilai tersebut menggunakan persamaan (4), (5), (6), (7) (Tomar et al, 2012).

$$
\begin{aligned}
& \text { Sensitivity }=[T P /(T P+F N)] \times 100 \% \\
& \text { Specificity }=[T N / T N+F P] \times 100 \% \\
& P P V=[T P /(T P+F P)] \times 100 \% \\
& N P V=[T N /(T N+F N)] \times 100 \%
\end{aligned}
$$

\begin{aligned} \multicolumn{4}{l}{ Keterangan: } \\ $T P \quad: \quad \begin{array}{l}\text { Sistem menghasilkan kesimpulan } \\ \text { positif untuk sampel data positif; }\end{array} \\ F P \quad: \quad \begin{array}{l}\text { Sistem menghasilkan kesimpulan } \\ \text { positif untuk sampel data negatif; }\end{array} \\ T N \quad: \begin{array}{l}\text { Sistem menghasilkan kesimpulan } \\ \text { negatif untuk sampel data negatif, dan }\end{array} \\ F N \quad: \quad \begin{array}{l}\text { Sistem menghasilkan kesimpulan } \\ \text { negatif untuk sampel data positif. }\end{array}\end{aligned}$

Menurut (Han dan Kamber, 2006), Confusion Matrix adalah cara yang 
berguna untuk menganalisis seberapa baik sistem mengenali tuple dari kelas yang berbeda. TP dan TN memberikan informasi ketika sistem benar, sedangkan FP dan FN memberitahu ketika sistem salah.

Sensitivity dan specificity dapat digunakan untuk pengklasifikasian akurasi. Sensitivity dapat ditunjuk sebagai true positives (recognition) rate (proporsi dari tuple positif yang diidentifikasi dengan benar). Sedangakan specificity adalah true negatives rate (proporsi tuple negatif yang diidentifikasi secara benar).

Fungsi sensitivitas dan spesifisitas dapat menunjukkan tingkat akurasi menggunakan persamaan (8) dan ukuran tingkat kesalahan sistem juga dapat dihitung dengan persamaan (9).

$$
\begin{gathered}
\text { Accuracy }=\text { sentitivity } P /((P \\
+N)) \\
+ \text { specificity } N \\
/((P+N)) \\
\text { Error Rate }=\frac{F P+F N}{(P+N)} \times 100 \%
\end{gathered}
$$

\section{PEMBAHASAN}

1. Akuisisi Pengetahuan

Case base akan dibentuk dari kumpulan data rekam medis pasien penyakit kandungan. Tahap berikutnya adalah melakukan akuisisi pengetahuan yaitu proses untuk mengumpulkan data-data pengetahuan dari sumber pengetahuan. Sumber pengetahuan tersebut dijadikan sebagai informasi untuk dipelajari, diolah dan diorganisasikan secara terstruktur menjadi basis pengetahuan. Sumber pengetahuan diperoleh dari seorang pakar (dokter spesialis). Selain pakar, bahan pengetahuan ini juga diperoleh dari literatur-literatur yang berkaitan dengan masalah tersebut, seperti buku, jurnal, artikel dan lain sebagainya. Data-data yang diperlukan di sajikan pada Tabel 1 dan Tabel 2.

\section{Tabel 1. Data penyakit}

\begin{tabular}{|l|l|}
\hline Kode & Penyakit \\
\hline P001 & Kista Indung Telur (Ovarium Cyst) \\
\hline P002 & Kanker Indung Telur (Kanker Ovarium) \\
\hline P003 & Kanker Leher Rahim (Kanker Serviks) \\
\hline P004 & Myoma Uteri \\
\hline P005 & Endometriosis \\
\hline P006 & $\begin{array}{l}\text { Kanker Rahim (Kanker Uterus = } \\
\text { Carcinoma Uteri) }\end{array}$ \\
\hline P007 & Penyakit Infeksi Daerah Panggul \\
\hline P008 & Chlamydia \\
\hline P009 & Gonorrhoea \\
\hline
\end{tabular}

Tabel 2. Data gejala

\begin{tabular}{|l|l|}
\hline Kode & Gejala \\
\hline G001 & $\begin{array}{l}\text { Rasa nyeri pada rongga panggul disertai rasa } \\
\text { agak gatal }\end{array}$ \\
\hline G002 & Perdarahan menstruasi tidak normal \\
\hline G003 & Siklus menstruasi tidak teratur \\
\hline G004 & Rasa nyeri begitu siklus menstruasi selesai \\
\hline G005 & Rasa nyeri sewaktu bersetubuh \\
\hline G006 & Perut membesar \\
\hline G007 & Tidak terjadi ovulasi \\
\hline G008 & Mandul \\
\hline G009 & Nyeri perut \\
\hline G010 & Gangguan fungsi saluran cerna \\
\hline G011 & Gangguan saluran kencing \\
\hline G012 & Berat badan turun drastis \\
\hline G013 & Nyeri punggung \\
\hline G014 & $\begin{array}{l}\text { Penderita bisa meraba sendiri tumor di } \\
\text { bagian bawah perut }\end{array}$ \\
\hline G015 & Perdarahan melalui vagina \\
\hline G016 & Perdarahan spontan \\
\hline$\ldots$ & dst \\
\hline G056 & Infeksi anus / rectum \\
\hline
\end{tabular}


2. Implementasi Sistem

Sistem dibagi menjadi 2 kategori berdasarkan jenis pemakai (pakar dan paramedis). Pakar berfungsi sebagai administrator sistem. Pakar bertugas untuk memasukan data pengetahuan (data penyakit, data gejala dan bobot gejala), data kasus serta perbaikan (revisi) kasus hasil diagnose serta diagnosa. Sedangkan Paramedis memiliki hak akses untuk memasukkan data pasien, melakukan diagnosa, serta menyimpan kasus baru.

Seorang user dapat menggunakan sistem sesuai dengan hak akses masing-masing, maka user tersebut harus melakukan login terlebih dahulu.

\section{Menu input data}

Menu pakar adalah menu yang hanya dapat diakses oleh user dengan hak akses sebagai pakar. Menu ini memiliki beberapa sub menu yaitu input data gejala, data penyakit, data kasus dan revisi kasus. Sub menu kasus adalah fasilitas sistem yang berfungsi sebagai antar muka untuk memasukan data basis kasus kedalam sistem. Sedangkan sub menu Revisi Kasus adalah fasilitas pakar untuk melakukan revisi terhadap kasus hasil diagnosa.

Form input data gejala dan input data penyakit adalah failitas untuk memanipulasi data gejala dan data penyakit yang akan disimpan dalam basis data. Tampilan form data gejala dan data penyakit masing-masing terlihat pada Gambar 3 dan 4 .

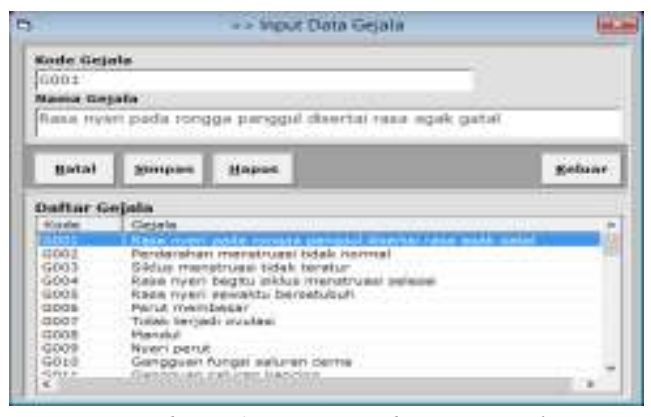

Gambar 3. Form data gejala

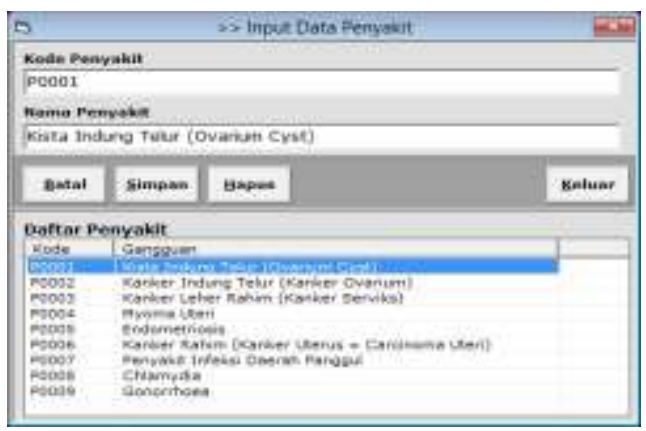

Gambar 4. Form data penyakit

Form input basis kasus digunkan pakar untuk memasukan data basis kasus sebagai source case dalam melakukan diagnosa kasus baru. Sebuah kasus terdiri dari beberapa gejala dan nilai bobot gejala tersebut terhadap penyakit dalam suatu kasus. Tampilan form basis kasus terlihat pada Gambar 5. 


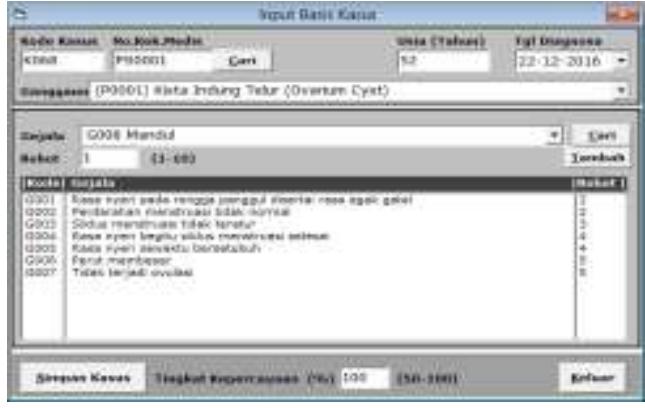

Gambar 5. Form basis kasus

Form Revisi Kasus digunkan oleh pakar untuk melakukan perbaikan terhadap suatu kasus. Perbaikan yang dilakukan dapat berupa perbaikan bobot masing-masing gejala dengan melihat penyakit pada kasus tersebut. Pakar juga dimungkinkan untuk mengganti penyakit pada kasus tersebut berdasarkan gejala yang muncul. Setelah direvisi kasus akan disimpan kedalam basis kasus dengan kode 1 yang berarti kasus tersebut akan digunakan sebagai source case untuk mendiagnosa kasus baru.

\section{Menu konsultasi}

Menu Konsultasi digunakan oleh user Paramedis untuk memasukan data pasien dan proses diagnosa kasus baru. User pakar juga dapat mengkases menu ini.

Data pasien terdiri dari kode pasien, nomor rekam medis, nama, tanggal lahir dan alamat pasien. Kode pasien akan diberikan secara otomatis. Field nama pasien, nomor rekam medis dan alamat pasien tidak wajib diisi untuk menjaga kerahasiaan pasien.

Proses diagnosa meliputi proses peng-inputan kondisi pasien, pemeriksaan/pencarian kasus terdahulu yang mirip dengan kasus baru (retrieve), menghitung tingkat kemiripan (similaritas) dan menyimpulkan hasil diagnosa berdasarkan tingkat kemiripan paling tinggi. Setelah semua data dimasukan, selanjutnya user harus mengklik tombol Hasil Diagnosa untuk mengetahui hasil diagnosa pasien tersebut.

Proses perhitungan dilakukan menggunakan persamaan (1). Tahap perhitungan kemiripan dilakukan dengan urutan sebagai berikut.

a. Setiap nilai kemiripan akan dikalikan dengan bobot masingmasing (similaritas lokal) kemudian hasilnya dipangkatkan dengan $r \quad=3, \quad$ kemudian dijumlahkan.

b. Menghitung jumlah bobot dari masing-masing fitur yang terlibat, kemudian dipangkatkan dengan $r$.

c. Membagi hasil point 1 dengan hasil point 2, kemudian dipangkatkan dengan nilai $1 / r$. 
d. Menghitung jumlah fitur pada kasus lama yang sama dengan fitur pada kasus lama, kemudian membaginya dengan jumlah fitur pada kasus baru sehingga dihasilkan nilai similaritas antara kasus baru dengan kasus lama (source case).

Setelah proses perhitungan similaritas masing-masing kasus yang memiliki kesamaan dengan kasus baru, langkah selanjutnya adalah mengurutkan nilai similaritas dari nilai tertinggi ke nilai terrendah. Kasus dengan nilai similaritas tertinggi adalah kasus yang paling mirip dengan kasus baru, kemudian solusi dari kasus tersebut akan direkomendasikan sebagai solusi kasus baru tersebut. Sehingga hasil diagnosa ditampilkan seperti pada Gambar 6.

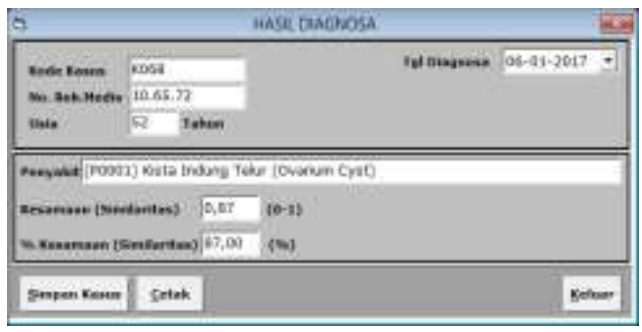

Gambar 6. Hasil diagnosa

User dapat menyimpan hasil diagnosa tersebut kedalam basis kasus. Jika nilai kemiripan mencapai nilai threshold yaitu minimal 0,8 atau $80 \%$ maka kasus tersebut akan disimpan dengan status 1 yang berarti dapat diikutkan dalam proses diagnosa kasus berikutnya. Jika nilai similaritas kurang dari 0,8 maka kasus tersebut akan disimpan dengan status 0, artinya kasus tersebut perlu mendapatkan revisi dari pakar dan tidak akan gunakan dalam proses diagnosa kasus berikutnya sebelum mendapat revisi dari pakar.

\section{Pengujian Sistem}

Proses pengujian sistem dilakukan dengan dengan menggunakan sampel data acak sebanyak $40 \%$ dari basis kasus (40 sampel kasus). Guna keperluan pengujian, ditambahkan 10 sampel kasus sebagai data uji yang bukan kasus penyakit kandungan. Langkah pengujian dilakukan dengan mengadakan diagnosa menggunakan sistem seperti dijelaskan pada bagian sebelumnya. Sistem dianggap berhasil mendiagnosa dengan benar jika menujukan tingkat similaritas lebih besar atau sama dengan $80 \%$. Grafik hasil uji sistem menggunakan sampel kasus penyakit kandungan di sajikan dalam grafik pada Gambar 7. Sedangkan grafik hasil uji sistem menggunakan sampel bukan kasus penyakit kandungan di sajikan dalam grafik pada Gambar 8. 


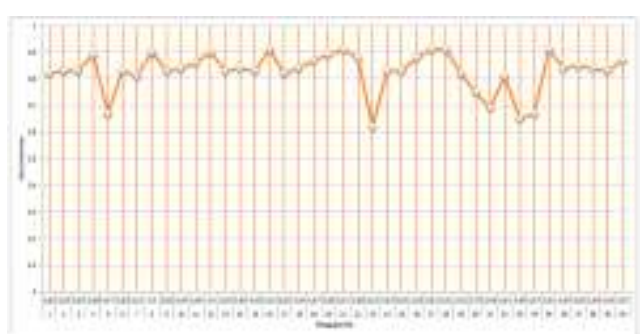

Gambar 7. Grafik hasil uji sampel penyakit kandungan

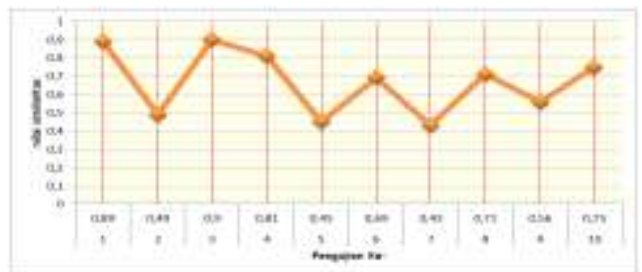

Gambar 8. Grafik hasil uji sampel bukan penyakit kandungan

Uji coba bertujuan untuk memastikan bahwa aplikasi telah berjalan dengan baik serta memberikan keputusan yang tepat. Hasil pengujian akan digunakan sebagai bahan evaluasi sistem. Evaluasi penting dilakukan untuk mengetahui apakah sistem yang dibuat layak diterapkan dalam mendiagnosa penyakit kandungan. Evaluasi hasil pengujian sistem dalam mediagnosa dilakukan dengan menghitung nilai sensitivitas, spesifisitas, $P P V, N P V$, akurasi dan error rate.

Setelah proses pengujian, tahap pertama yang harus dilakukan adalah membuat confusion matrix berdasarkan nilai similaritas hasil pengujian sistem, seperti terlihat pada Tabel 3.
Tabel 3. Confusion matrix hasil pengujian sistem

\begin{tabular}{|c|c|c|c|}
\hline \multicolumn{4}{|c|}{ Data Uji Sistem } \\
\hline & \begin{tabular}{c|} 
Penyakit \\
Kandungan
\end{tabular} & $\begin{array}{c}\text { Bukan } \\
\text { Penyakit } \\
\text { Kandungan }\end{array}$ & $\begin{array}{c}\text { Total } \\
\text { Kasus }\end{array}$ \\
\hline $\begin{array}{l}\text { Similaritas } \geq \\
0.8 \text { (Positif) }\end{array}$ & 34 (TP) & $2(\mathrm{FN})$ & $36(\mathrm{P})$ \\
\hline $\begin{array}{l}\text { Similaritas < } \\
0.8 \text { (Negatif) }\end{array}$ & $6(\mathrm{FP})$ & $8(\mathrm{TN})$ & $14(\mathrm{~N})$ \\
\hline Total Kasus & 40 Kasus & 10 Kasus & $50(\mathrm{P}+\mathrm{N})$ \\
\hline
\end{tabular}

Confusion matrix pengujian sistem menunjukan sebanyak 34 sampel pasien penyakit kandungan terdiagnosa positif pada sistem dan sebanyak 6 sampel yang terdiagnosa negative. Sedangkan pengujian dengan menggunakan sampel pasien bukan penyakit kandungan, hasil yang diperoleh dari proses diagnosa menggunakan sistem 2 terdiagnosa positif dan 8 sampel terdiagnosa negatif. Berdasarkan data tersebut dapat dihitung tingkat sensitivitas, spesifisitas, $P P V, N P V$, akurasi dan error rate menggunakan persamaan (4), (5), (6), (7), (8) dan (9).

a. $\quad$ Sensitivitas $=\frac{34}{(34+2)} \times 100 \%=$ $94,44 \%$

b. Spesifisitas $=\frac{8}{(8+6)} \times 100 \%=$ $\mathbf{5 7 , 1 4} \%$

c. $\quad P P V=\frac{34}{(34+6)} x 100 \%=85,00 \%$

d. $\quad N P V=\frac{8}{(8+2)} x 100 \%=80,00 \%$

e. $\quad$ Akurasi $=94,44 \% x\left(\frac{36}{(36+14)}\right)+$ $57,14 \% x\left(\frac{14}{(36+14)}\right)=84,00 \%$

f. $\quad$ Error rate $=\frac{(6+2)}{(36+14)} \times 100 \%=$ $16,00 \%$ 
Hasil perhitungan diatas menunjukan persentase kemampuan sistem dalam mengenali penyakit kandungan secara benar sebesar 94,44\% (sensitifitas), persentase kemampuan sistem dalam mengenali penyakit bukan penyakit kandungan secara benar sebesar 57,14\% (spesifisitas), nilai prediksi positif sebesar $85,00 \%(P P V)$, nilai prediksi negatif sebesar 80,00\% (NPV), dan tingkat akurasi sebesar 84,00\% (accuracy) dengan tingkat kesalahan (error rate) sebesar 16,00\%. Berdasarkan hasil pengujian yang dilakukan diatas maka dapat disimpulkan bahwa sistem case-based reasoning ini sudah dapat berfungsi untuk melakukan diagnosa awal penyakit kandungan dengan tingkat akurasi lebih dari $80 \%$. Akan tetapi masih perlu di perhatikan terkait tigkat kesalahan yang masih cukup tinggi, hal ini mungkin dipengaruhi jumlah dan variasi sample kasus yang digunakan dalam basis kasus.

\section{KESIMPULAN}

Berdasarkan tahapan penelitian sampai dengan pengujian sistem yang telah dilakukan, dapat disimpulkan bahwa penerapan metode modified weighted minkowski dalam sebuah sistem penalaran berbasis kasus dapat berjalan dengan baik. Sistem yang dikembangkan dapat digunakan sebagai sarana untuk melakukan diagnosa penyakit kandungan yang terdiri dari 9 penyakit yaitu, kista indung telur, kanker indung telur, kanker leher rahim, myoma uteri, endometriosis, kanker rahim, penyakit infeksi daerah panggul, chlamydia dan gonorrhoea.

\section{DAFTAR PUSTAKA}

Aamodt, A., dan Plaza, E., 1994, Case-Based Reasoning: Foundational Issues, Methodological Variations, and System Approaches. AI Communications, Vol. 7, 39-59.

Akobeng, A.K., 2007, Understanding diagnostic tests 1: sensitivity, specificity and predictive values, Acta Pcediatrica, Vol. 96 No. 3, ISSN:1651-2227, Halaman 338341.

Belkhirat, A., Belkjir, A., dan Bouras, A., 2011, A New Similarity Measure for the Profiles Managemant, UKSim 13th International Conference on Modeling and Simulation, IEEE Computer Society, DOI 10.1109/UKSIM.2011.55

Faizal, E., 2013, Case-Based Reasoning untuk Mendiagnosa Penyakit Cardiovascular dengan Metode Weighted Minkowski, Tesis, S2 Ilmu Komputer UGM, Yogyakarta.

Faizal, E., 2014, Penerapan Teori Damster-Shafer pada Sistem Cerdas untuk Mendeteksi Gangguan Kesehatan Kandungan, Jurnal Fahma, Vol 12 No. 3, 
September 2014 ISSN 1693-2277, Yogyakarta.

Han, J., dan Kamber, M., 2006, Data Mining: Concepts and Techniques Second Edition, Morgan Kauffman, ISBN 978-92-4156437-3, San Fransisco.

Kusrini, 2006, Sistem Pakar: Teori dan Aplikasi, Penerbit Andi offset, Yogyakarta.

Kusumadewi, S., 2003, Artificial Intelence : Teknik dan Aplikasinya, Graha Ilmu, Yogyakarta.

Pal, K. S., dan Shiu, K.C.S., 2004, Foundations of Soft Case-based Reasoning, A John Wiley \& Sons, Inc., Publication, New Jersey.

Seetha, M., Sunitha, K.V.N., dan Devi, M., 2012, Performance Assessment of Neural Network and K-Nearest Neighbour Classification with Random Subwindows, International Journal of Machine Learning and Computing, Vol. 2, No. 6, pp 844-847.

Tomar, P.P.S., Singh, R., Saxena, P.K., dan Sharma, B.K., 2012, A Medical Multimedia Based DSS for Heart Diseases Diagnosis and Training, Canadian Journal on Biomedical Engineering \& Technology Vol. 3 No. 2.

Yatim, F., 2005, Penyakit Kandungan, Pustaka Populer Obor, Jakarta. 